ISSN: 2576-2141

\title{
Refugee Perspectives on Integration in Germany
}

\author{
Cüneyt Gürer ${ }^{1}$ \\ University of Siegen, Germany
}

\begin{abstract}
This study will examine the integration process from the perspectives of refugees by focusing on individual and social level experiences. Data for this study comes from individual-level semistructured and focus group discussions collected over a period of seven months in Germany and covers refugees who applied for asylum after 2015. Keeping in mind the fact that the meaning of integration differs for different audiences, this study identifies five distinct phases of refugee integration in Germany. In each phase, refugees face certain challenges that hinder their integration into local communities. These phases, with some minor differences, may also be applicable to other countries, and therefore this study offers a general framework to analyze the integration process from refugee perspectives. Individual and social dimensions of integration analyzed and individual adjustment and coping mechanisms demonstrated throughout the study. This study suggests that refugees should be more involved in the definition of integration and more importantly, social and professional interaction through "entry points" should be encouraged for successful integration of refugees.
\end{abstract}

KEYWORDS: Refugees, Integration, Adaptation, Integration Policies.

\section{Introduction}

According to the UN Refugee Agency, 70.8 million people displaced by active wars, conflict, and persecution at the global level and these numbers have been increasing at least for the last eight subsequent years (around 40 million people in 2011 and more than 70 million in 2018.) (UNHCR, 2019a). In the latest example, Syria produced most of the displacement in the world and since the beginning of the conflict, more than 13 million people fled from the country (more than 6 million internal and 5.6 million external displacements observed) (UNHCR, $2019 b)$. More recently, the political crisis in Venezuela created a displacement of 4,5 million people to neighboring countries (UNHCR, 2019c). The global scale of forced displacement and refugees reached its record level and the international community fails to produce long term solutions to reduce these numbers and cannot effectively address the root causes of displacement.

UNHCR (2019d) statistics indicate that almost $60 \%$ of refugees are coming from three countries; Syria (6,7 million), Afghanistan (2,7 million) and South Sudan (2,3 million) and at the global level $80 \%$ of refugees live in the neighboring countries which are mostly developing countries with scarce sources and limited capacity to manage large numbers of people. Starting from the early phases of the conflict in Syria, Turkey hosts 3,6 million Syrian refugees and became the highest number of refugee-hosting countries in the world. Although Turkey pursued

\footnotetext{
${ }^{1}$ Corresponding author; cuneytgurer@gmail.com
} 
an open-door policy towards Syrian refugees at the earlier phases of the crisis, failure of policies to integrate refugees in Turkey created a large influx of people towards Europe in 2015 (Aydin, Gundogdu, \& Akgul, 2019; Gürer, 2018). Recently Turkey started discussions about creating a "safe zone" in northern Syria and relocate Syrian refugees to this area (Wintour, 2019). Integration to host societies become more important as expectations fade for a peaceful solution in the regions of conflict producing migration flows, particularly in Syria. The most recent development in the region increases the unpredictability of future perceptions of refugees in countries where they are mostly populated. Recent discussion of creating a "safe zone" 2 for refugees in Northern Syria, along the Turkish border, added more uncertainty and complication to already a very complicated issue of human displacement in the region. Turkish example showed that managing crises with an open door policy solves immediate problems, however long term policies to integrate refugees in host communities are an essential part of the ongoing refugee challenge for many countries. ${ }^{3}$

Germany received 1.1 million people in 2015 alone, the biggest number of refugees in Europe, which created political and social debates about refugees in German society. Although German bureaucracy overwhelmed with the number of arrivals, State institutions, in cooperation with civil society and NGOs, has managed better than might have been expected to absorb a large number of refugees. However, Fratzscher (2018) argues that the challenge to make integration successful is still ahead and it will be one of the most difficult postwar economic, social, and political challenges since German reunification. Germany continued to receive refugees in the flowing years and almost 200.000 people applied for asylum in 2018 (AIDA, 2019a).

Refugees in every country go through different stages of adaptation and participation to host societies and each stage requires well-designed integration policies to reduce negative outcomes and increase the level adaptation to the new social environment. Integration policies and associated procedures are mostly bureaucratic in nature and in many cases; the interaction between refugees and the host country is a "one way street" from institutions to individuals. The term integration lacks a clear understanding by different actors in the process, which leads to not having clear expectations of host communities from refugees and eventually not being able to reach a defined objective through integration policies. The United Nations High Commissioner for Refugees (UNHCR) defines integration as "a dynamic and multifaceted twoway process which requires all parties concerned" (UNHCR, 2005). The European Union (EU, 2018) provides a similar definition and a comprehensive action plan laying out specific actions for member states to be successful in the integration of refugees. The EU action plan requires member states to take measures starting from pre-departure and pre-arrival to active participation in society. Refugee integration is implemented through a number of measures in several priority areas: learning the official language of the host country, access to education, employment and healthcare, family reunion, social assistance, recognition of skills and qualifications, participation in the social and cultural life of the host community. All these

\footnotetext{
${ }^{2}$ Although discussions of a safe zone at the Northern Syria go back as early as the beginning of Syrian crises in 2011, more recently Turkish President Erdogan explicitly demanded creating a safe zone in Syria to re-locate Syrian refugees living in Turkey (3,6 million people). Germany participated the discussion of creating the safe zone by offering an "international safe zone" rather than only Turkey and Russia operates in the region. Considering the complicated nature of the regional political and security dynamics, this paper only focuses on how "safe zone" discussions increase the level of uncertainty for refugees living both in Turkey and in Europe since proposals of safe zone have no clear plan and implementation strategy, at least during the writing of this study.

${ }^{3}$ Official Turkey policy towards Syrian refugees always shaped around the term "guest" and never used the term integration rather used harmonization. For the details and background of Turkish refugee policies please refer to $\begin{array}{llll}\text { Hoffmann and Samuk (2016), https://www.swp- } & \end{array}$ berlin.org/fileadmin/contents/products/arbeitspapiere/Working_paper_Hoffmann_Turkish_immigration_policy.p df
} 
measures and tools are considered key factors for successful refugee integration. (Dimitrov \& Angelov, 2017)

The overall objective of the study is to understand the interaction between the individual, society, and institutions by focusing on refugee perspectives in the integration context. It will also bring an alternative look to the refugee policy and will demonstrate the need for adaptation of policies based on the emerging and changing needs of refugees during their integration to host communities. Developing such a system requires interaction between the system (rules regulations, bureaucratic structure, and agents of the system, etc.) and refugees.

Refugee integration has many aspects but most defining characteristics of the process, at least at the early phases, are the official procedures that refugees go through in host societies. Official perspective defines integration with steps regulated by rules and procedures, which are, in most cases, produces tangible and measurable results. However, official procedures and formal definitions of integration pay little attention to how refugees understand and interpret the process. When we look at the same process from the perspective of refugees themselves, we see a much different, more complex and dynamic process. This study is an attempt to understand the process of integration from the perspective of refugees and provides an alternative understanding of integrating refugees into host communities.

\section{Individual and Social Aspects of Integration Process}

The value of refugee input into the integration process and policy changes have not been discussed and studied extensively in the literature. Active participation of refugees to integration is reduced to expectations of the host state and following the official steps designed by-laws, rules and other regulations. At the societal level, the definition of integration and expectations of host communities might be different from each other, based on the characteristics of local communities. At both levels, official and social, refugees are anticipated to fill the expectation of (formal and informal) rules of the host society. Their interpretation of the process and changing the nature of needs and demands mostly overlooked. However, their interpretation and understanding of the process of integrations are critical to reaching a successful level of integration. The involvement of refugees in the integration process is necessary as not only objects (being observed and less contribution expected) but also subjects (the observer and active contributor). In order to make the integration more interactive and "two-way" process, policymakers, experts, and scholars should consider looking at the integration process from the refugee perspective and understand how refugees perceive, understand and interpret the process.

Understanding individual contributions to the process by collecting subjective interpretations will help us to see the differences between official expectations and individual perceptions. When we add the individual (objective) background factors such as (level of education, previous work experience, professional and personal achievements, etc.), it would be possible to increase our understanding of the process from the perceptions of refugees rather than making our assessment solely based on the official definitions and measurements of integration. Consideration of refugee experiences will also help to reduce the sources of tensions and possible negative outcomes of the process which are created by the failures. Ultimately, it has the potential to help increase the likelihood of successful participation of refugees in host communities.

Figure-1 presents the main actors of the integration process and direction of the interaction. Official integration policies demand refugees to follow certain steps and complete requirements defined by the national and international rules and regulations. Although these are an important part of the integration process, they represent only a small portion of a complete understanding of integration. The third major factor in the integration process is the Society as the determinant of the refugees' behavioral outcomes, cultural adaptations and the level of social 
interaction. Taking society as a dependent variable (being influenced by other factors to identify their demands from refugees) will extend the model presented in Figure-1 and it will be possible to increase our understanding of social demands by adding new variables such as the role of media, political choices, level of heterogeneity, etc. However, this study limits itself considering society as an independent variable (influencing refugee integration with its demands) but not go into details of how these social demands are shaped.

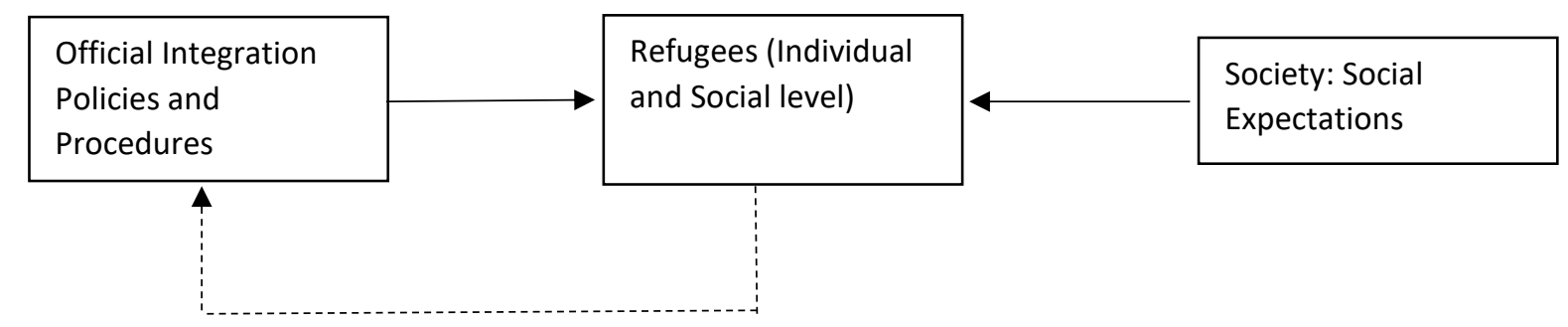

Figure 1. Interaction between main actors of the integration process.

The displacement process itself and following the adaptation process to new social environments produce uncertainties and require individual-level coping mechanisms. According to Ward and Kennedy (1999; in El Khoury, 2019, p.66), this process has two major aspects; psychological adaptation and sociocultural adjustment. Psychological adaptation refers to the individual-level well-being and mental health of the person, and sociocultural adjustment is related to the ability of the individual to obtain social skills to function in the new society (El Khoury, 2019). Her findings indicate that language acquisition, maintaining social contacts in the host community, and living in private housing rather than refugee establishments are the most important predictor of successful integration to host communities.

\section{Data and Methodology}

Qualitative data provides an in-depth understanding of human behavior and allows better examination of complexities of a situation using open-ended questions with flexible interaction throughout the interview (Flick, 2014). The data for this study comes from individual and focused group interviews with 28 individuals with a refugee background who applied for asylum in Germany. The data collected as a part of the study supported by Alexander von Humboldt Foundation in Germany which examines the integration process within the larger context of conflict displacement and integration. In the time of the interview, almost half of the participants (13 individuals) of this study applied for asylum but did not receive the final decision of their application. The rest of the interviewees are recognized asylum seekers from Turkey, Syria, and Iraq and they were attending German language courses during the interview period. The level of the educational background of the individuals is high (mostly University graduates and 5 people with Masters degrees) and almost all of them had a professional career (min 5 years and max 25 years) before they arrived in Germany. The majority of the participants are male and only four females represented in the data. Using the model presented by Gürer and Akgül (2019) this study extends the understanding of phases of displacement and integration by inserting individual-level experiences into their model. Gürer and Akgül (2019) demonstrate (Figure-2) a process of displacement starting before refugees leave their country of origin. They take pre-displacement conditions and consider their effects on other stages of the displacement. Their model looks at the individual refugee experiences at four levels; international, national/state, national/social and individual level. This study focuses on the individual and social level experiences of refugees during their displacement and integration process. 


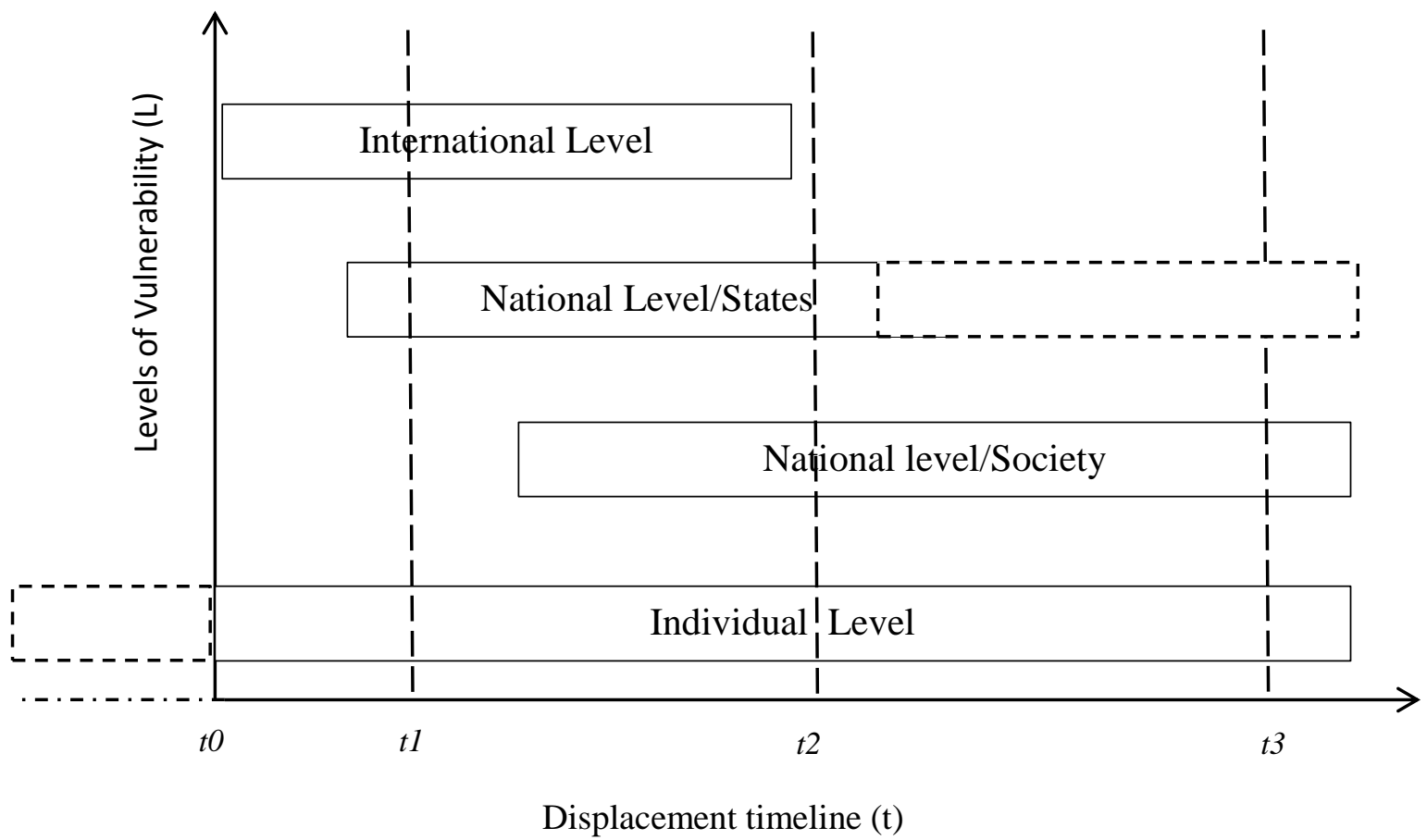

Figure 2. Levels of vulnerability on a timeline.

Source: Adapted from Gürer and Akgül (2019).

Using the same model as a theoretical base, this study provides empirical data to examine the integration challenges of individuals by starting the process of integration from pre-arrival conditions and continue by exploring the first contact of refugees with the host country's official process. After individuals start their official process they follow the official integration step designed by the relevant bureaucratic structures based on the normative requirements. The data collected during the interviews will be analyzed using these official stages that refugees go through during their integration process. Using this framework and taking an analytical approach will allow us to examine the perspectives of refugees and how they identify the process. It will also help us to show the difference between bureaucratic understanding and individual interpretation of the same process. As a result of the preliminary analysis of the data collected for this study and a thorough examination of the integration process, this study identified five major stages to use as an analytic framework. These stages are; Pre-arrival, first contact with the official process and application to asylum, official integration process, social and professional entry points and long term participation into host communities. Each step examined from individual and social perspectives and the following matrix (Table-1) presents the framework and main arguments. 
Table 1

Five Stages of Integration and Individual/Social Dimensions

\begin{tabular}{|c|c|c|c|}
\hline & Conditions & $\begin{array}{l}\text { Impact on the } \\
\text { Individual }\end{array}$ & Social Consequences \\
\hline Pre-Arrival & $\begin{array}{l}\text {-Conflict } \\
\text {-Escape from } \\
\text { danger } \\
\text {-Hiding }\end{array}$ & $\begin{array}{l}\text {-Fear } \\
\text {-Exposed to violence } \\
\text { and victimization } \\
\text {-Trauma }\end{array}$ & $\begin{array}{l}\text {-Exclusion and losing } \\
\text { social attachments } \\
\text {-Social status lost } \\
\text {-Disconnection from } \\
\text { family }\end{array}$ \\
\hline $\begin{array}{l}\text { First contact } \\
\text { with the official } \\
\text { process }\end{array}$ & $\begin{array}{l}\text {-Lack of knowledge } \\
\text { about the process } \\
\text {-Waiting in the } \\
\text { refugee camp }\end{array}$ & $\begin{array}{l}\text {-Ambiguous } \\
\text { bureaucratic process } \\
\text { and feeling helpless } \\
\text {-Communication } \\
\text { challenges and losing } \\
\text { self-esteem }\end{array}$ & $\begin{array}{l}\text {-Not being able to } \\
\text { establish social } \\
\text { contacts } \\
\text {-Feeling lonely } \\
\text {-Exclusion from } \\
\text { society }\end{array}$ \\
\hline $\begin{array}{l}\text { Official } \\
\text { Integration } \\
\text { Process }\end{array}$ & $\begin{array}{l}\text {-Language and } \\
\text { integration courses }\end{array}$ & $\begin{array}{l}\text {-Losing the value of } \\
\text { mother language } \\
\text {-Not being able to } \\
\text { communicate the } \\
\text { language of the host } \\
\text { nation }\end{array}$ & $\begin{array}{l}\text {-Limited social } \\
\text { connection due to } \\
\text { language disability } \\
\text {-Seeking help from } \\
\text { people speaking the } \\
\text { same or a common } \\
\text { third language }\end{array}$ \\
\hline Entry Points & $\begin{array}{l}\text {-Developing social } \\
\text { and professional } \\
\text { mechanisms of } \\
\text { engagement } \\
\text {-More social and } \\
\text { professional } \\
\text { interaction }\end{array}$ & $\begin{array}{l}\text {-Feel more included } \\
\text { and get familiar with } \\
\text { social norms } \\
\text {-Obtain information } \\
\text { to continue previous } \\
\text { professional career }\end{array}$ & $\begin{array}{l}\text {-More attachment to } \\
\text { society } \\
\text {-Improve language } \\
\text { capacity through } \\
\text { interactions } \\
\text {-Professional networks } \\
\text { and a clear } \\
\text { understanding of the } \\
\text { job market }\end{array}$ \\
\hline $\begin{array}{l}\text { Long term } \\
\text { participation }\end{array}$ & $\begin{array}{l}\text {-More stable } \\
\text {-More interaction } \\
\text { with the community } \\
\text {-Ability to pursue } \\
\text { daily tasks without } \\
\text { assistance }\end{array}$ & $\begin{array}{l}\text {-More positive and } \\
\text { taking more } \\
\text { responsibility } \\
\text {-Establishes an } \\
\text { individual comfort } \\
\text { zone }\end{array}$ & $\begin{array}{l}\text {-Better relations with } \\
\text { society } \\
\text {-More social } \\
\text { engagements and } \\
\text { participation in social } \\
\text { events } \\
\text {-The family starts } \\
\text { having daily routines }\end{array}$ \\
\hline
\end{tabular}

\section{Refugee experiences and their impact on the individual}

In combination with the pre-displacement events, refugee experiences at different stages, until a stable living condition, changes many aspects of the individual life. During this process, the individual faces many uncertainties and loss of previous life. Identity of the individual, previous professional achievements, and losing social status create an environment that requires strong coping mechanisms. Even the individual reaches a more stable condition after the displacement and arriving in the host country, most of these and related problems 
remain and the individual realizes that most of the previous life conditions could never be reestablished. In some cases, the severity and the length of such pressures break the previous understanding about the self and others. These pressures also challenge individuals' meaning systems, including beliefs about the world and their ability to envision future goals (Matos, Indart, Park, \& Leal, 2018). Long term disconnection from previous professional and social environments increases the risk of mental health problems and failures in the integration of individuals to the host communities (Norris, 2016).

Refugees experience multiple stressful and even traumatic conditions that have a significant psychological impact on individuals. Strang and Quinn (2019) argue that because of "multiple losses and experiencing acutely distressing events before fleeing their homes and during their journeys", refugees might develop mental health problems, lose the sense of identity and confidence. The entire process of displacement requires a complete understanding of its effect on individuals and how the individual developed coping mechanisms to ease the pressure of the process. Bemak and Chung (2017) state that most of the time refugees' departure from their country of origin is sudden and without having enough time for planning and preparation. Many uncertainties about their destinations, travel routes, means of travel and risks during the travel put refugees under immense pressure and put them into psychological and physical danger (Bemak \& Chung, 2017, p. 299).

During different stages of displacement and integration process, individual perception of "self" challenged by the approach of the new social environment to refugees. Unpredictability and unclear messages increase the level of doubts about individual values, capacities and create a gap between the individual now and the individual then. Most of the participants interviewed for this study indicated such feelings that both during the displacement process and integration, they had difficulty to feel the gap between the previous self and how they define their identity now. In a focus group interview of the participant voiced what they all agree to call "bitter truth" by stating;

"We lost our status and we will not be able to get it back. Many of us accomplished a lot in our previous lives, but it is is different now. We have to accept that. We will not be able to reach the same levels what we have accomplished before." (Group Interview on 02 Feb. 2019)

According to Williams and Nida (2017, p.5), the self consists of self-concept, selfesteem, and self-consciousness. These are all affected by significant changes and dramatic life events. Refugee experiences (fear of persecution, escape from intolerable conditions, displacement and other sources of pre-migration trauma) are considered to be important elements of psychological impact on refugees. Self-concept is challenged by the new circumstances and by the outside look to the individual as a refugee rather than the dominant aspect of the identity. As the individual being pushed to the identity framework created by the official process or by the society in everyday interactions, the gap between the individual selfconcept reduces to how the outside world perceives the individual. This interaction is likely to have a negative impact on individual self-esteem.

\section{Refugee experiences and social Interactions}

At every stage of adaptation to a new environment, the individual constantly evaluates the surrounding environment and makes adjustments based on the feedback from these interactions. Individuals also define their roles in society by observing other people's reactions to them. In his classical theory of the looking-glass self, Charles H. Cooley (1902, in Yeung \& Martin, 2003) claims that "self is a result of the social process whereby we see ourselves as others see us." Therefore, social interaction defines who we are and our definition of our 
identities. Limited interactions with the outside world, especially after traumatic events or sudden changes in social life could have severe effects on how individuals see and interpret the world around them (Gürer \& Akgül, 2019). After leaving their country of origin, refugees lose their previous social connection which also affects their perception of identity. Their new social environment and interactions define their new self-perceptions. In other words, refugees' selfconcept is shaped by their social interactions which eventually influence the re-shaping of refugees' new identities in the host societies.

Limited social contact and interaction with the members of the host community also reduces the likelihood of integration and lead refugees to develop relationships with communities that they share the same language and culture. When individuals during their integration process need assistance, having no contact from host communities gives no option but to seek help from communities that shares the same language and culture. One can argue that those communities are also part of the host society and such an approach might produce positive results for integration. However, those communities, in most cases, have their own integration problems and trust within these communities is not very well established. In addition to these structural problems, especially for political asylum seekers, contact with communities from the country of origin brings some risks therefore, they either stay isolated or become a part of a selective group in these communities. Not developing social interactions with mainstream society puts refugees in the already established diaspora or closed communities which hinder integration process in the long run.

In our interviews most of the participants indicated that they had difficulty to contact local communities to solve their immediate problems such as learning about the education system, communicating with bureaucracy, finding housing, etc. Therefore most of the people asked for help from other people from a similar national and cultural background. In a recent study, Röing (2019) found that Turkish asylum seekers in the state of North Rhein Westphalia in Germany mostly contacted Turkish organizations that they found similar to their political views and social background. The same study further indicates that even in the Turkish communities there is a big difference in understanding each other and different political affiliations determine who refugees would contact. Turkish refugees have difficulty to develop out-group relationships and create new contacts due to their reluctance to become the target of their own government. In this case, differences originating from their home country and political affiliations increase the risk of isolation of refugees in host communities. One participant of this study who previously worked as a civil servant stated that;

"the only option I have at the moment to continue my social life is to stick with people who are called Gülen supporters. They are the people who became victims of persecution in Turkey and whoever comes to Germany after 2016 more likely to be considered as a Gülenist anyways. Yes, it is true that you can get help from these people, from their organizations, but having no other social option is a different thing. I prefer having more German friends rather than being only with these people, even they help me a lot. I feel like I am stuck in Turkey even I know that I live in Germany now. I have to break this circle and have more contacts and more friends from Germany." (Individual interview \#16 on 18.10.2018)

My field notes during the data collection combined with my own experiences in the process also reflect that during early phases of the integration process, establishing social connections is very important but difficult to do at the same time; 
At every stage of the integration process, the lack of social interaction is the main problem. Starting from the early stages of asylum application the later stages in the process of official integration establishing connections with the local people is the most difficult one. The full picture of difficulties establishing such relationships could be examined from both sides; why people have little engagement with foreigners and why refugees have the reluctance to get in touch with local populations. Language is definitely the number one issue for early stages and knowing another common language such as English gives an advantage at every level but not on every occasion. For example, when I wanted to develop professional connections, English language skills helped me to get in touch with people and meet them to discuss my situation or to express my needs. In any engagement in society, you realize that German language skill is the defining issue for further connections. This is true, for example, regarding our relationship with our neighbors. Not being able to speak perfect German we cannot develop strong relations. (Field Notes, April 2018)

\section{Defining Major Steps of Integration of Refugees}

The German Federal Office for Migration and Refugees (BAMF) divides the official procedure for asylum applications in Germany in 9 distinct stages. ${ }^{4}$ Application to asylum starts with the arrival and registration of refugees at the reception centers and follows by the initial distribution and accommodation. Personal asylum application, follow up interviews and the final decision outcome of the process (including the appeal process in case of denial) completes the application process. These stages reflect the legal and administrative procedural steps for refugees to follow and represent the official side of the process, which takes between 6 months to 2 years and includes changing of accommodation and residing cities several times.

The use of integration as a central term by different host community actors, referring to adaptation of individuals to host communities, starts at the very early stages of the process. Starting from the arrival refugees hear "integration" as a word that means different things for different people. When they live in a refugee camp, integration mostly means respecting camp rules and understanding the social environment, however the same word when it is used by a local official might mean something else. One of the participants of this study argued that;

"When I make something wrong, or even different, the common answer that I hear from people is 'this is Germany and it does not work in Germany' then they start talking about we need to learn how things work here and it comes to how much I need the integration. When they help me to understand how it should be and give me concrete explanations, this type of talking does not bother me at all because it helps me to learn. However, most of the time I just listen how much I need to integrate but receive no specific information about what I need to do, I learn nothing from people just telling me I need to integrate, what do they mean by integration anyways?"

\footnotetext{
${ }^{4}$ Details of these stages can be found in the following document published by BAMF: "The State of the German Asylum Procedure: An overview of the individual procedural steps and legal bases" available online at https://www.bamf.de/SharedDocs/Anlagen/EN/Publikationen/Broschueren/das-deutsche-asylverfahren.html
} 
This statement reflects the confusion of the individual when they start feeling the pressure from the outside world to integrate into the host community but not knowing the expectations clearly. In some cases, integration as a word choice, used against refugees to highlight the need for them to learn how things work in Germany and adapt to many things around them. However, this approach does not really help refugees to integrate rather re-enforce the feeling of exclusion and remind them that they are not a natural part of the society and they have a process to complete to be recognized as a full member of the society. Another problem with this approach is that it does not have a clear understanding of what a refugee should do to be considered integrated. Highly skilled refugees and people experienced living in other Western countries feel the same pressure from society and for them also it is confusing what society means by integration. Therefore, integration is not only a concept that requires refugees to understand and do their part for a better adaptation but also it has to be defined and expectations out of this definition should be clearly identified for refugees.

\section{Main Stages of Adaptation and Integration}

Human displacement is a long and challenging process. Individuals in the process of displacement go through various difficulties most of them continue at later stages. Displacement starts when people decide to leave their home, continue during their journey and even last after their arrival and during their stay in the host country. It is possible to identify three major steps of displacement; pre-departure, transit (journey) and reaching to the destination. Each phase has its own specific conditions for refugees to cope with and should be closely examined to obtain a clear understanding of the entire process. The theoretical assumption of this paper connects these major phases and argues that each face interacts with each other. Based on the interviews and data collected for this study, five major phases, that refugees go through, are identified. These phases are related to pre-arrival conditions (including their travels and journey), asylum application process and social integration stages; 1Conditions of Pre-Arrival, 2- First contact with the official process, 3- Official integration process, 4- Attempting to find "entry points" to the society and 5- Long term participation

\section{1- Conditions of Pre-Arrival to Host Nation}

Pre-arrival conditions are incidents forcing refugees to leave their country and experiences they have gone through both in the home country and during their journey. Before leaving their countries, refugees face economic hardship and social disruption connected to persecution and armed conflict in their home countries (Ager, 1999). The influence and effect of these pre-departure problems continue during the displacement process and new challenges emerge during the travel. In most cases, violence and life-threatening events combined with experiences during the travel, including their protracted stay in the transit countries create an immense amount of negative effects on individuals. In this study, most of the participants had experiences that still create a significant amount of stress on them. Participants revealed some of the following problems during the interviews that are still affecting their daily lives; losing connection with their family members (including the time they had to hide from government oppression at the country of origin), separation from family after leaving the country, and not knowing when and how to see them again, being exposed to violence during detention and experience of imprisonment, being exposed to psychological pressures and threats from government forces extending to their families.

After crossing the border, many people reached Greece expecting to find a way to continue their journey towards Western European countries. A number of participants indicated that they, in addition to their payment to smugglers (between 3000 Euro - 10.000 Euro per person), had to make extra payments to get false documentation to continue their journey. They 
also argued, in addition to the financial challenges of the displacement process, they found themselves in the middle of a criminal world which became their only option for protection. It is a situation that they "would never think about being involved and never imagined criminals become their only option to protect their dignity." What they called it "losing their level" and a process of "from belonging to non-belonging" meaning that "all previous life experiences and status lose its meaning and not having options puts you in a position that you never think for your self." As one of the participants clearly indicated, "a crime that I never committed and fabricated by the government follows me like a ghost." (Group Interview on 20.05.2019 in Cologne)

The same conditions forcing individuals to leave also creates a psychological impact on refugees that last until later stages of the integration process. Most of the participants of this study indicated that they had some sort of negative experience with the government officials in the home country, having been harassed and faced with misbehaviors. One of the participants of this study indicated that;

"What is waiting for me in Turkey is worse than anything else. Therefore, I try to ease the difficulties that I face here by thinking about how life was horrible for me back in Turkey. A constant fear of being subject to behaviors of the government of officials (police, prosecutor and guards in prison), being threatened by people who know who I am. It was a total nightmare. I cannot go through that fear again. Many people became a victim of constant government aggression and alienation from society. I had to hide for more than two years. I lived in a room and never went outside, my body never saw sunlight because I had to keep the curtains closed all day and could not have a light in the evening. I don 't even want to remember now." (Individual interview \#18 on 15.05.2019)

Many people try not to remember the difficulties they have gone through during their stay in the home country. However, without getting professional help, individuals carry negative impacts of pre-flight events. The level of difficulty they faced at the home country reduces the making demands and exploring their rights in the host country rather enforces to accept whatever is provided for them and therefore become a passive object of the process.

Pre Arrival conditions, such as individual exposure to violent conflict or being subject to persecution or ill-treatment as well as living under difficult conditions are all important to understand the current conditions of individuals who are applying for asylum. These conditions with other challenges in the initial process of application can also be important determinants of the quality of later stages of integration. Understanding the pre-arrival conditions will also help to identify the specific challenges such as the consequences of cultural, religious and other identity-related differences that the individual has been going through during the displacement period.

\section{2-First contact with the official process: Arrival registration and life in the refugee camp}

The second major step for refugees after arriving at the host state is starting the official process of an asylum application by reporting to any security or immigration authority, reception facility, and an arrival center. Application to asylum starts with an initial registration process and until they are called for their first interview, they are obliged to wait in refugee camps. That is the moment when the long waiting process starts. In the context of Germany, the time until the first interview varies according to the place where the application made. According to German Federal Office for Migration and Refugees (BAMF) in 2018, the average 
time of application procedures was 8 months and average time until a final decision was 16.8 months (including court process in case of an appeal) (AIDA, 2019b).

\section{Life in a refugee camp}

Most people at this stage live in either refugee camps or facilities that are designated for them and shared with other people. Living in a refugee camp disconnects people from mainstream society and limits refugees' social options. Our study indicates that at this stage refugees also could not receive information regarding the later stages of their application process due to the lack of an informative interaction with the people who are providing services at the accommodation facilities. Some of these problems emerged due to a lack of German language capacities and not having direct contact with the officials processing application or not having regular updates of the process. Each day refugees living in camps are advised to follow the transfer or registration lists which are posted on the boards in a common area of the camp. Some of the people interviewed for this study stated that "they have to wait and check the information board at the camp whether they have their names on the list for a transfer or for any other thing that might be important for them. "Interviewers also claimed that it is almost impossible to think life outside the camp because the conditions and requirements "keep you in the camp and do nothing but wait until you hear something about yourself." This constant feeling of depending on the information that would be provided on the board creates stress over the individual because of not knowing when the expected information will appear. "It could be tomorrow or next month," says one of the participants and continues "that is a life lived by the board, our main information provider" (Individual interview \#8, 17.10.2018).

At the early stages of the asylum application process and mandatory stay in refugee camps take months and during this process, the unpredictability of the later stages and waiting become the nature of life. In order to reduce the stress and make camp life easier this unpredictability can be reduced through alternative information channels. Another important point highlighted by the people who participated in this study is limited resources to fill the time during this waiting period. They claimed, where they live, they did not have many options for activates especially for children and young people. Most people participated in this study highlighted the need for more activities both for adults and children at refugee camps to use the time more effectively and in a productive way. They claim language courses and being able to participate in social activities in the region, rather than being isolated from communities would be better for later stages of integration.

Overall perceptions of life and future prospects of refugees are significantly different when they live in or outside the camp. Haase, Rohmann, and Hallmann (2019) found in their study that refugees living in asylum centers reported more psychological problems and more perceived discrimination than those living in independent housing. Another important finding of their study is about the family situation of refugees and indicates that refugees who are alone, away from their families in Germany reported more psychological problems than those living in Germany together with their families. People living in the camp are more pessimistic about the way their life develops and as time passes they claim to have more difficulty to explain the situation to their children. One of the essential steps after difficult situations in the country of origin is normalization of life which also reduces the psychological impact of past events on children. However, normalizing life in a refugee camp is not an easy thing to do for many parents.

The feeling of helplessness is an important aspect of living in refugee camps. The waiting period for asylum application decision seems to affect the individual and each family member in different ways. As one the participant couple indicated that their children were constantly asking when they would have "a normal home and be able to feel the warmness of having own home". This family stated they have been avoiding invitations from people to their 
homes thinking that the visit would remind their situation to their children and as a result, they choose to close themselves to the outside world until they have the right to obtain their own apartment. They argued that life in the camp gives children the feeling of inferiority and the more they engage with the outside world the more they feel that they consider themselves unequal and they are not like people living outside the camp. This feeling of losing selfconfidence can take years to overcome with other challenges on top of it such as, in the later stages, the lack of language capacities not being able to fit into other children at school, etc.

One of the psychological conditions and feelings of refugees observed during the data collection process was the lower self-esteem of people residing in refugee camps. During the group interviews, it was easy to identify people who are living in camps as they were showing signs of low confidence in their statements and about having an impact on their future. People living in camps during the interview preferred not to make strong claims about what they want or what they know about their surrounding environment, on the other hand, individuals living in their own apartments made stronger claims about the similar topics discussed during the interview. Personality factors should be controlled before making a general conclusion about this finding, however, on several occasions individuals themselves also indicated that they have lost their self-confidence after they started living in refugee camps.

The passive environment of the camps and not being able to connect to the world around them reduce the sense of self and force individuals questioning the meaning of life and his/her abilities to cope with challenges of the future. In a camp environment, refugees seem to be living between two worlds and between two identities. The first world connected to the first identity is the one which basically reflects the life before the displacement. The second is constructed during the process of displacement and continues all the way to the later stages of asylum application and integration process. The gap between the first and the second identity creates a condition of anomie (Durkheim, 1951; Merton 1968) which might eventually cause strain and reduction of self-esteem (Owino \& Weber, 2019). Actual exclusion or the perception of being excluded in a refugee camp might have devastating consequences on the individual. Williams, Forgas, and Von Hippel (2005, p. 2-3) argue that social outcasts and ostracism might have detrimental effects on an individual which may not heal over the years. Refugees could have the feeling of being isolated from mainstream society due to the conditions in camps or force themselves to self-isolation as a result of losing self-esteem and develop a perception of not-belonging to any social groups.

\section{Personal asylum applications and interviews}

After the first interview refugees are called for another interview which is the most important of all other steps in the process affecting the outcome of the asylum application. By design, it is a bureaucratic process and the actors involved in the interview have specific roles and set of behavioral norms to be expected from them. In its ideal form, the interviewer is the government agent asking questions to understand the applicant's position of seeking refuge and whether or not the claims made fit the definition of refugee status in international and national regulations. The applicant is the person who is being interviewed (interviewee) and also expected to give the most accurate information about her/his situation related to the claim for refuge. The interview is an interactive process that each individual involving the interview constantly affecting the behavior of the other. Asylum interview is not only bounded to the individual interactions and social-psychological environment of the interview setting, it is also highly connected to the previous events and future expectations of the applicant. All these factors have a combined effect on the storytelling and to some extent on the outcome of the interview (to grant asylum or not).

In this environment, applicants found themselves in a rather stressful condition between what happened in reality and what (and how) bureaucracy actually wants to hear it. One of the 
findings of this study indicates that in most cases bureaucracy only interests the facts that are directly related to the application and the entire story of displacement with its emotional consequences are ignored. Woolley (2017) indicates that "the process is based on a refugee's ability to provide a credible account of their persecution and, where possible, to prove the authenticity of their claim through documentary evidence" however she also argues that "in practice, the process relies heavily on the self-presentation of the individual claimant; their ability to convince an immigration officer or judge. The claimant must narrate themselves into a position of legitimacy." In their investigation of asylum interviews, Puumala, Ylikomi, and Ristimäki (2017) found out that asylum narratives are subject to the influence of bureaucratic, interactional and psychological elements that are both expressed verbal and non-verbally during the interview. They argue that verbal accounts are considered as the most important aspect of the asylum stories and non-verbal actions (or non-actions) are in most cases considered not relevant.

In this setting, applicants are expected to tell their stories in a structured way and most of the time answer the questions they have been asked and not to go details of the events that are not relevant directly to their case. Following are some of the issues highlighted by the people interviewed for this study indicating their understating and experience of the interview process;

\begin{abstract}
-I had this feeling I had to make my case clear but I was not sure how to do that without explaining the events around it. My officer thought these are irrelevant and general issues but without telling them my cases did not have much value for my officer. I was not able to impress the officer. (In this particular case, the applicant believes that the officer should be impressed and the case should be different than many other people. It might also be interpreted not as to impress but to convince the officer.) (Individual interview \#10, 18.12.2018)
\end{abstract}

-I was so stressed and was not able to talk without taking deep breaths. I knew what I would tell in that room and how I would tell that had a powerful impact on my family's future. We have waited for the interview so long and everybody said something and during the interview, I don't even remember any of them (the interview started with a high level of stress due to the possible impact of the interview on the future) (Individual interview \#14, 07.02.2019)

-We have explained our story to other people in the camp assuming they would the people who were going to make the decision we were wrong. I don't understand why we have given so much information to these people and which information will be more valuable now for this interview. I am tired of telling my story over and over. (The lack of knowledge about the administrative structure and several occasions of talking with officials at different levels force them to tell their entire story and with limited interest from these authorities, the applicant lost interest telling the story) (Individual interview \#16, 06.03.2019)

\title{
3- The Official Integration Process
}

The official integration process starts with the registration to an integration course. Learning the German language is the main component of the official integration process. The second part of the integration course is the orientation course which covers the subjects of life in Germany, politics, state structure, standards, and values of the society. Language courses 
create an interactive environment for people from different backgrounds and significantly improve their language skills, however in most cases language courses designed to teach language based on the standard teaching methods which cover grammar and test skills. People in that stage demonstrated that they needed more interaction with native speakers outside classroom settings. Some language courses provide free conversation classes that people can attend which is helpful to practice the language. However, attending social gatherings to improve the interaction with native speakers and being part of other types of social engagements considered more valuable and desirable.

\section{4-Attempt to find "entry points" to the society (more than integration) $)^{5}$}

The official integration process, with its emphasis on language training and some formal classes about history, politics and social life does not provide the actual entry points for refugees to adapt and integrate them into society. According to the German Federal Office for Migration and Refugees (BAMF, 2019), over 90\% of the refugees (who arrived in Germany after 2015 and applied for asylum) had a weak command of the German language upon their arrival. Comparing the 2016 data with a new wave collected in 2017, the same report indicates that $71 \%$ of refugees who completed official integration and language courses managed to reach, as it is coded by the survey, a "good" or "very good" level of German language capacity.

Gürer (2019) argues that the following stages of the integration process should focus more on including refugees into the economic and social systems of the society and, he further suggests that for effective integration and more positive outcomes, multiple entry points and opportunities for the individual should be established. Entry points are interaction mechanisms for individuals with local communities and societal institutions at the local level. Gürer (2019) argues that establishing a professional entry point means "a connection with a professional environment that may provide insights and conditions enabling individuals to continue with a similar profession that fits their background." Social entry points help people to develop social attachments that they need both in coping with psychological challenges and establishing a new social environment in the integration process.

Individuals participated in this study claimed that social and professional interactions will help them not only to speak German better but also it will contribute to their social and professional integration. Without having social interactions, successful completion of language courses will not automatically result in better integration into society. Gürer (2019) therefore argues that more interaction with local communities is an emerging need for refugees in Germany. He further claims that putting entry points into practice will only require adaptation of existing institutions to the needs of refugees and increasing the visibility and accessibility of present programs.

\section{5-Long term participation, adaptation and integration outcomes}

This stage starts when the individual develops a complete understanding of the host society, general structure of the job market, and establishes social attachments as well as obtains a level of language capacity to pursue daily life without needing anyone to provide guidance. Individual base identity re-construction continues at this stage with a combination of previous homeland identity and a new identity. Hermans (2018, p. 288) argues that individual lives in three distinguished zones in their self-space; comfort, challenge and danger zones. Comfort zones reflect our space where we feel safe and relaxed. Our natural tendency keeps us to stay

\footnotetext{
${ }^{5}$ The idea of "entry points" examined in this part has been presented by the author at the German Refugee Studies Network Blog and available at : https://blog.fluchtforschung.net/social-and-professional-entry-points-in-thegerman-refugee-integration-policy/
} 
in our comfort zones unless we want a change motivating us to take a position in the challenge zone. In the long term participation stage, refugees start developing a comfort zone that provides a predictable social and professional environment. The unfamiliar, stressful, or traumatic situation, temporarily or permanently force us to the danger zone where strong negative emotions, uncomfortable, threatened and unsafe feelings will dominate our behavioral pattern.

Initial refugee experiences, until reaching a level of comfort creates a constant and a protracted stay in the danger zone, until reaching this stage. Refugees struggle to find an appropriate place in the host society and try to accomplish the basic human need for belonging. The need for belonging is a need to be satisfied at every stage that has been discussed until now, however it is more important at this stage as the individual prioritizes developing a relationship and meaningful participation to the society. In the absence of such meaningful connections, the individual will have a perception of exclusion and rejection by the host society. ${ }^{6}$ Considering the socially dependent nature of human beings, the feeling of exclusion and rejection may have devastating effects on individuals and groups made of these individuals (Gürer \& Akgül, 2019). Research indicates that social exclusion and rejection can lead to aggressive and anti-social behavior (Catanese \& Tice, 2005). Hogg and Wagoner (2017, p. 207) also state that uncertainty resulting from normative exclusion can be resolved by identifying with extremist groups. In order to reduce the uncertainty about the identity, the individual develops a connection with a group that reduces self-uncertainty. In order to go back to confidence zone, individuals tend to join groups that meet the urgent need of belonging and also give a clear understanding of group norms and expected behaviors by dictating how one behaves and perceives the world and how one is in turn perceived and treated by the outside world.

\section{Conclusions}

This study examined the integration process by focusing on the refugee perspectives and their individual and social experiences in the process. After collecting data about the process of integration in Germany, this study developed five categories of integration that refugees go through. Pre-arrival conditions are considered as a separate phase of the integration because most people show signs of being influenced by the challenges they have faced before they arrive. This phase even overlaps with other phases and effects the level of future prospects and refugees' attachment to host society. After their first contact with the official process of the asylum system, refugees spend some amount of time waiting for the process of application and finalization of their application (according to German Federal Office for Migration and Refugees, BAMF, in 2018, average waiting time for application procedures is 8 months and for final decision 16.8 months.) During this time, most people stay in refugee camps or some other type of shared accommodation. This study found that staying in refugee camps for a longer time time period affects people's self-perceptions, reduces self-confidence and reduces the contacts with the host community.

Another challenge for refugees during their waiting period for the decision of their application is the information gap about the individual asylum application process. At the early stages of the asylum application having better functioning information channels between bureaucracy and individual applicants is critical both reducing the stress of waiting and unpredictability of the process by providing a clear picture of the bureaucratic process of the asylum application. This interaction will provide more clarity for people about their environment and it will have a positive impact on individuals. During this time individuals can engage different activities that will help them to increase their capacities for later stages of

\footnotetext{
${ }^{6}$ Williams et al. (2005, p. 2-3) defines social exclusion as "not being included within a given social network (but not necessarily ignored) and rejection as "an explicit verbal or physical action that declares that the individual is not wanted as a member within a relationship group.
} 
integration. During the official integration process which mainly focuses on the language and integration courses, refugees have certain level of interaction with other refugees and host communities, however this phase might be improved by adding more activities of engagement with the host society through activities of non-governmental organizations and society base associations.

Many integration programs financed by the German government, private sector or by the EU provide significant opportunities for refugees to develop their social and professional attachment to society. During the data collection process, this study identified the fact that many refugees did not know much about the programs provided by these organizations, and these organizations had difficulty to reach individuals who might need their programs. Therefore, better coordination between refugees and social initiatives are needed to improve the success of integration. Finally, this study argues, refugees need both social and professional entry points to a society that will allow them to feel more included and attached to the social structure and norms of the host communities. With these entry points, long term participation and integration will be more successful. Most of the people interviewed for this study were in the early stages of their integration, therefore the last two stages of the model created for this study still require more input. Future studies could look at how refugees develop social and professional attachments, how they develop networks of integration and unique challenges of later stages of integration. Comparison of the model amongst different communities in Germany and with other European countries will also allow gaining more information about the process of refugee integration.

\section{Declaration of Conflicting Interests}

The author declared no potential conflicts of interest with respect to the research, authorship, and/or publication of this article.

\section{Funding}

The data collected for this paper is a part of research supported by Alexander von Humboldt Foundation Philipp Schwartz Initiative and hosted by the University of Siegen in Germany

\section{References}

Ager, A. (1999). Perspectives on the refugee experience. In A. Ager (Ed.), Refugees: perspectives on the experience of forced migration (pp. 1-23). London and New York: Pinter.

AIDA. (2019a). Asylum information database. Germany country report, Retrieved from http://www.asylumineurope.org/reports/country/germany

AIDA. (2019b). Asylum information database, regular procedure. Germany Country Report. Retrieved from https://www.asylumineurope.org/reports/_country/ germany/asylumprocedure/procedures/regular-procedure

Aydin, H., Gundogdu, M., \& Akgul, A. (2019) Integration of Syrian refugees in Turkey: Understanding the educators' perception. Journal of International Migration and Integration, 20(4), 1029-1040.

BAMF. (2019) Kurzanalyse: Geflüchtete machen fortschritte bei sprache und beschäftigung (Refugees make progress in language and employment). Retrieved form https://www.bamf.de/SharedDocs/Anlagen/DE/Publikationen/Kurzanalysen/kurzanaly se1-2019-fortschritte-sprache-beschaeftigung.pdf?_blob=publicationFile 
Bemak, F., \& Chung, R. C-Y. (2017). Refugee trauma: Culturally responsive counseling interventions. Journal of Counseling \& Development, 95, 299-308. doi:10.1002/jcad.12144

Catanese, K. R. \& Tice, D. M. (2005). The effect of rejection on anti-social behaviors: Social exclusion procedures aggressive behaviors. In K. D. Williams, J. P. Forgas, \& W. Von Hippel, The social outcast: Ostracism, social exclusion, rejection, and bullying. Psychology Press.

Cooley, C. H. [1902] (1983). Human Nature and the Social Order. Transaction.

Dimitrov, A., \& Angelov, G. (2017) Refugee integration in the EU : Challenges and economic impact. Economic Alternatives, (4), 584-600.

Durkheim, E. (1951) Suicide. The Free Press, New York.

El Khoury, S. J. (2019). Factors that impact the sociocultural adjustment and well-being of Syrian refugees in Stuttgart - Germany, British Journal of Guidance \& Counselling. 47(1), 65-80.

European Union, (2018). The action plan in the integration of third-country nationals. Retrieved from https://ec.europa.eu/home-affairs/what-we-do/policies/legalmigration/integration/action-plan-integration-third-country-nationals_en

Flick, U. (2014). An introduction to qualitative research (5th ed.). Thousand Oaks, CA: Sage.

Fratzscher, M. (2018). The Germany illusion: Between economic euphoria and despair. Oxford University Press.

Gürer, C. (2018, July 23). What's next for 3,5 million Syrian refugees in Turkey? Global Center for Security Studies Report. Retrieved from http://www.gc4ss.org/?p=870.

Gürer, C. (2019). Social and professional "entry points" in the German refugee integration policy. The German Network of Forced Migration Researchers (Netzwerk Fluchtforschung) Blog. Retrieved from https://blog.fluchtforschung.net/social-andprofessional-entry-points-in-the-german-refugee-integration-policy/

Gürer, C., \& Akgül, A. (2019) Conflict, human displacement and integration: Exploring the vulnerability of refugees. In M. Boskovic (Ed.), Globalization and its impact on violence against vulnerable groups (pp. 26-51). Hershey, PA: IGI Global.

Haase, A., Rohmann, A., \& Hallmann, K. (2019) An ecological approach to psychological adjustment: A field survey among refugees in Germany, International Journal of Intercultural Relations. Elsevier, 68(February 2017), (pp. 44-54). doi:10.1016/j.ijintrel.2018.10.003.

Hermans, H. J. M. (2018). Society in the self: A theory of identity in democracy. Oxford

Hoffmann, S., \& Samuk, S. (2016). Turkish immigration politics and the Syrian refugee crisis. Working Paper Research Division Global Issues (No. 01). Retrieved from https://www.swpberlin.org/fileadmin/contents/products/arbeitspapiere/Working_paper _Hoffmann_Turkish_immigration_policy.pdf

Hogg, M. A., \& Wagoner, J.A. (2017) Normative exclusion and attraction to extreme groups: Resolving identity-uncertainty. In K. D. Williams, \& S. A. Nida, Ostracism, exclusion, and rejection. Taylor \& Francis.

Matos, L., Indart, M. L., Park, C., \& Leal, I. (2018). Meaning-making and psychological adjustment following refugee trauma. Presented at the 12th National Conference on Health Psychology - Promote and Innovate in Health Psychology, At Lisbon, Portugal. Retrieved on 03.06.2018 at https://www.researchgate.net/publication/322802026_ Meaningmaking_and_psychological_adjustment_following_refugee_trauma

Merton, R. K. (1968). Social theory and social structure. Free Press: New York.

Norris, D. R. (2016). Job loss, identity, and mental health. Rutgers University Press.

Owino, J., \& Weber, C. D. (2019). Explicating anomie in refugee women's integration narratives: A qualitative research study. International Journal of Intercultural Relations, 74,69-79. 
Puumala, E., Ylikomi, R. and Ristimäki, H. (2017) 'Giving an account of persecution: The dynamic formation of asylum narratives', Journal of Refugee Studies, 31(2), 197-215. doi:10.1093/jrs/fex024.

Röing, T. (2019). Fortsetzung politischer Konflikte oder Neuanfang? Türkische Geflüchtete in Nordrhein-Westfalen, BICC (Working Paper No.6). Retrived from https://www.bicc.de/publications/publicationpage/publication/fortsetzung-politischerkonflikte-oder-neuanfang-tuerkische-gefluechtete-in-nordrhein-westfalen/

Strang, A. B., and Quinn, N. (2019) Integration or Isolation? Refugees' Social Connections and Wellbeing. Journal of Refugee Studies, Fez040, doi:10.1093/jrs/fez040

UNHCR. (2005) Executive Committee, Conclusion on Local Integration, No. 104 (LVI) 2005, preamble (j) and (k). Retrieved from https://www.unhcr.org/excom/exconc/ 4357a91b2/conclusion-local-integration.html

UNHCR. (2019a), Global Trends Forced Displacement in 2019, Retrieved from https://www.unhcr.org/globaltrends2018

UNHCR. (2019b). Syria emergency. Retrieved from https://www.unhcr.org/syriaemergency.html

UNHCR. (2019c) Venezuela Situation, Retrieved fromhttps://www.unhcr.org/venezuelaemergency.html

UNHCR. (2019d) Figures at Glance, Retrieved from https://www.unhcr.org/figures-at-aglance.html

University Press.

Ward, C., \& Kennedy, A. (1999). The measurement of sociocultural adaptation. International Journal of Intercultural Relations, 23(4), 659-677.

Williams, K. D., \& Nida, S. A. (2017). Ostracism, exclusion, and rejection. Taylor \& Francis.

Williams, K. D., Forgas, J. P., \& Von Hippel, W. (2005). The social outcast: Ostracism, social exclusion, rejection, and bullying. Psychology Press.

Wintour, P. (2019, September 24). Recep Tayyip Erdoğan proposes 'safe zone' for refugees in Syria. Retrieved from https://www.theguardian.com/world/2019/sep/24/erdoganproposes-plan-for-refugee-safe-zone-in-syria.

Woolley, A. (2017). Narrating the "Asylum Story": Between literary and legal storytelling. Interventions, 19(3), 376-394.

Yeung, K., \& Martin, J. (2003). The looking glass self: An empirical test and elaboration. Social Forces, 81(3), 843-879.

Manuscript received November 19, 2019

Final revision received November 29, 2019

Accepted December 29, 2019 